\title{
Insulation Saving Effect for Korean Apartment House Using Cross-Laminated Timber $(\mathrm{CLT})^{1}$
}

\author{
Sung-Jun Pang ${ }^{2} \cdot$ Bumjin Lee ${ }^{3} \cdot$ Gi Young Jeong (D) ${ }^{2, \dagger}$
}

\begin{abstract}
The aim of this study was to develop the details of cross-laminated timber (CLT) envelops for satisfying the design standard for energy saving (DSEA) and passive standard in South Korea. When the same thickness of $180 \mathrm{~mm}$ concrete or CLT was used and the same materials for other layers were used for the roof, wall, and interlayer floor, the required insulation thickness for the different building envelopes in central, southern, and Jeju island was evaluated. As a result, compared to the concrete envelop, about $43 \mathrm{~mm}$ of insulation thickness was reduced for wall and roof with the CLT envelope. When the CLT envelopes were modified to protect the CLT from moisture based on FPInnovations (2011), the insulation thickness was further reduced by $12 \mathrm{~mm}$. When the modified CLT building envelops satisfied with a passive standard are used for 10-story building, the required insulation was decreased by $40.89 \mathrm{~m}^{3}$ for a floor $\left(105.27 \mathrm{~m}^{2} \times 2.3 \mathrm{~m}\right.$ in height) compared to concrete building. As the number of floors increases, about $3.58 \mathrm{~m}^{3}$ of insulation per floor was additionally saved.
\end{abstract}

Keywords : insulation, cross-laminated timber, Korean-style apartment house, building envelope

\section{INTRODUCTION}

Recently, high-rise buildings (7 to 18 stories) using cross laminated timber (CLT) as a structural member have been built around the world (CTBUH, 2017). An excellent dimensional stability (Brandner et al., 2016) and high strength-to-weight ratio made CLT to be replaced steel or concrete in high-rise building construction (Mallo and Espinoza, 2014). In ad- dition, wood has about 10 times lower thermal conductivity than concrete (Fadai, 2012; Seo et al., 2016). If a CLT uses instead of a concrete, the insulation would be saved.

In order to apply CLT to concrete buildings in South Korea, the design standard for energy saving (DSES) should be satisfied (Ministry of Land Transport Notice 2017-71, 2017). The standard specifies the insulation performance of the building envelopes according to the part of

1 Date Received October 24, 2017, Date Accepted November 10, 2017

2 Department of Wood Science and Engineering, Chonnam National University, 77 Yongbong-ro, Buk-Gu, Gwangju 61186, Republic of Korea

3 School of Architecture, Chonnam National University, 77 Yongbong-ro, Buk-Gu, Gwangju 61186, Republic of Korea

† Corresponding author: Gi Young Jeong (e-mail: gjeong1@jnu.ac.kr, ORCID: 0000-0003-2971-0631) 
the building envelops, roof, floor, wall, etc. as well as three regions, central, southern, and Jeju island. Thus, the details for the CLT building envelops for satisfying the DSES should be developed.

The energy consumption of house is depending on the thermal conductivity of construction materials as well as the arrangement of the house, floor area, sidewall insulation, window type, etc. Yoo et al. (2002) investigated the various factors on the energy consumption of Korean apartment houses and summarized the arrangement and envelop compositions for Korean apartments that are commonly constructed. In this study, the summarized envelop compositions for Korean apartments are used for developing CLT envelop composition.

The thermal performance of domestic wood frame houses have been evaluated by several researchers. Kim et al. (2013 a) evaluated the energy efficiency of domestic wood frame house using a building energy simulation program. Kim et al. (2013 b) evaluated the energy consumption of wooden building and focused on the thermal conductivity of the wood used in stud for wooden structure. They revealed the importance of thermal conductivity of structural wooden member. Kim and Park (2015) developed the details of post-beam timber house for satisfying the DSES and passive house. However, the detail for the CLT envelop has not been officially reported for satisfying the DSES.

The aim of this study was to develop the details of CLT envelops for satisfying the DSES and a passive standard in South Korea.

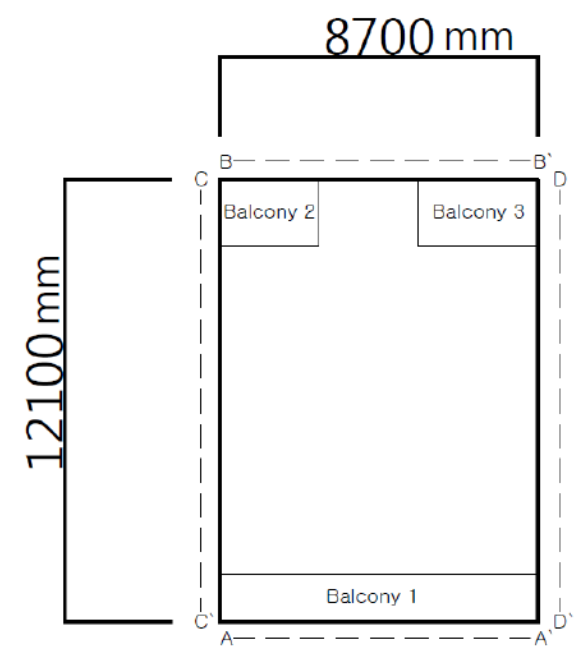

Fig. 1. Simplified floor plan of Korean apartment house (modified from Yoo et al., 2002).

Especially, the insulation saving effect was investigated in Korean apartment house by using a structural material for CLT instead of concrete.

\section{MATERIALS and METHODS}

\subsection{Simplified model and building envelops for actual Korean apartment house}

A building envelop can be constructed in various ways using variety of building materials. It can be significantly different by the designer. Thus, in order to propose a reasonable CLT building envelop and analysis the advantage of the proposed envelop system, a typical model is needed that can represent an actual building.

Yoo et al. (2002) suggested a simplified model to calculate thermal load for actual typical Korean apartment houses floor plan (Fig. 1). 
Table 1. Thermal conductivity of materials for building envelops

\begin{tabular}{ccc}
\hline Materials & Thermal conductivity $(\mathrm{W} / \mathrm{m} \cdot \mathrm{K})$ & Source \\
\hline \hline Gypsum board & 0.210 & \multirow{2}{*}{ Yoo et al., 2002 } \\
\hline Expanded polystyrene & 0.035 & \\
\hline Concrete & 1.620 & \multirow{2}{*}{ Kim et al., 2013 } \\
\hline Autoclave lightweight concrete & 0.170 & 1.510 \\
\hline Mortar & 0.370 & 0.174 \\
\hline Develing mortar & 0.370 & 0.170 \\
\hline Membrane waterproofing & & \\
\hline
\end{tabular}

Table 2. Area and window ratio of building envelops

\begin{tabular}{ccc}
\hline Position & Area $\left(\mathrm{m}^{2}\right)$ & Window ratio* $^{*}$ \\
\hline \hline A-A $^{\prime}$ & 20.01 & 0.8 \\
\hline B-B $^{\prime}$ & 20.01 & 0.4 \\
\hline C-C $^{\prime}$ & 27.83 & 0 \\
\hline D-D' & 27.83 & 0 \\
\hline Floor & 105.27 & 0 \\
\hline Roof & 105.27 & 0 \\
\hline
\end{tabular}

*the ratio of the window area to the corresponding exterior wall area

The simplied model was validated by comparing montly required thermal load between the simplied model and actual floor plan. In addition, they summarized the detail of typical building envelops (Fig. 2) as well as the thermal conductivity of typical building materials (Table 1). Table 2 shows the external area in different positions in Fig. 1 and the window ratio which is the ratio of window area to the corresponding exterior wall area. The simplified floor plan and the summarized information were used to compare the CLT envelops with concrete envelops in this study.

\subsection{Thermal transmittance of CLT}

The thermal performance of a building envelops is determined by thermal transmittance (U-value). The U-values of buildings envelops in Korea should satisfy the tabulated criteria in the DSES (Table 4). Meanwhile, a passive house requires the higher $\mathrm{U}$-value criteria as shown in Table 4 (PHIK, 2017). The U-value is calculated using Eq. (1). The calculation takes account of the internal and external heat transfer resistance, $R_{i}$ and $R_{o}$. The $R_{i}$ and $R_{o}$ values are specified in the design standard for 
Insulation Saving Effect for Korean Apartment House Using Cross-Laminated Timber (CLT)

Table 3. Density of domestic species at $12 \% \mathrm{MC}$ and thermal conductivity by Eq. (1)

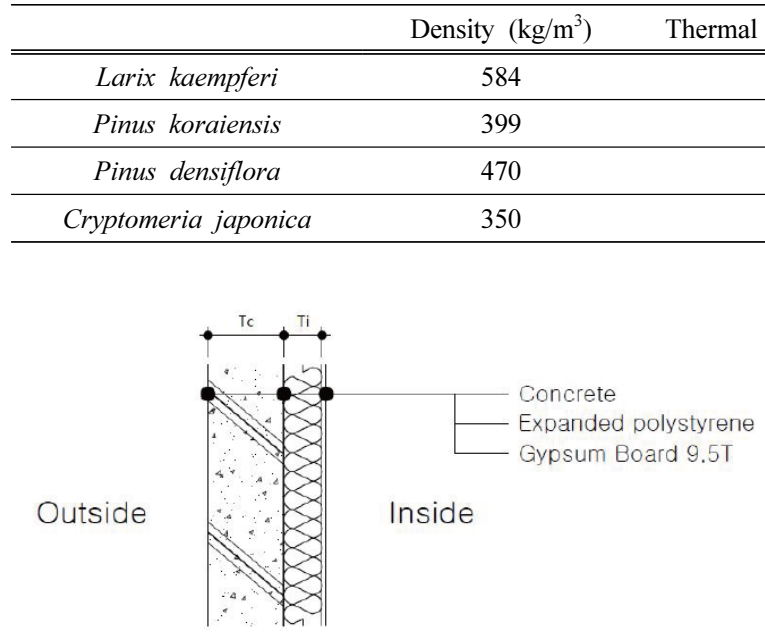

(a) wall

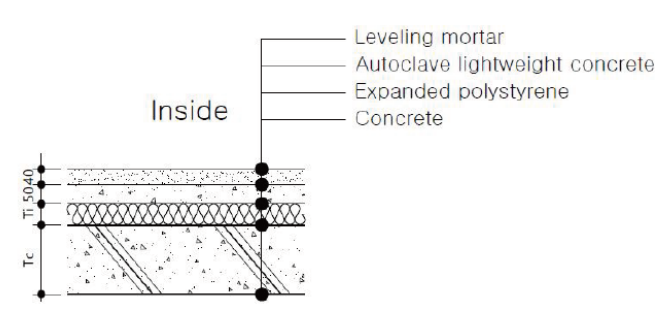

Outside

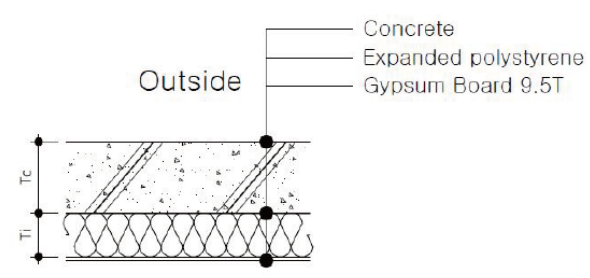

Inside

(b) roof

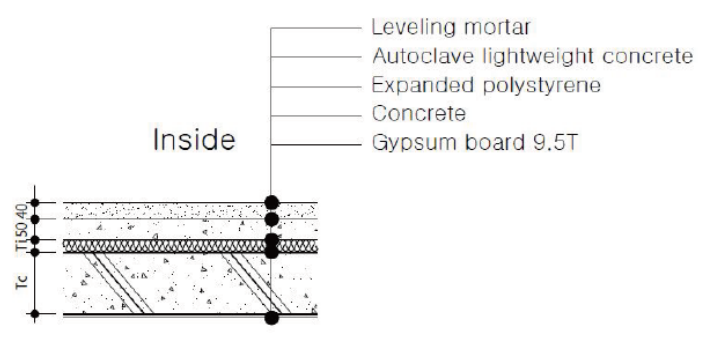

Inside

(c) bottom floor

(d) interlayer floor

Fig. 2. Details of Korean apartment envelops with concrete as a main structural material (modified from Yoo et al., 2002).

energy saving. The $R_{i}$ and $R_{o}$ for wall faced outdoor air are 0.11 and $0.043 \mathrm{~m}^{2} \cdot \mathrm{K} / \mathrm{W}$, respectively. The $R_{i}$ and $R_{o}$ for roof faced outdoor air are 0.086 and $0.043 \mathrm{~m}^{2} \cdot \mathrm{K} / \mathrm{W}$, respectively. The $R_{i}$ for interlayer floor is $0.086 \mathrm{~m}^{2} \cdot \mathrm{K} / \mathrm{W}$.

$$
U=\frac{1}{R_{i}+\sum \frac{x_{i}}{k_{i}}+R_{o}}
$$

where,

$U$ : thermal transmittance (U-value) $\left(\mathrm{W} / \mathrm{m}^{2} \cdot \mathrm{K}\right)$ $R_{i}:$ the internal heat transfer resistance $\left(\mathrm{m}^{2} \cdot \mathrm{K} / \mathrm{W}\right)$ $R_{o}$ : the external heat transfer resistance $\left(\mathrm{m}^{2} \cdot \mathrm{K} / \mathrm{W}\right)$ $x_{i}$ : thickness of material (m) $k_{i}$ : thermal conductivity $(\mathrm{W} / \mathrm{m} \cdot \mathrm{K})$

The location, thickness, and thermal conductivity $(k)$ of the materials used must be known in order to calculate the U-value. The thermal conductivity of wood is essentially de- 
Table 4. Insulation thickness (mm) for concrete and CLT envelops in Korean apartment

\begin{tabular}{|c|c|c|c|c|c|c|c|}
\hline \multirow{2}{*}{$\begin{array}{l}\text { Building } \\
\text { envelop }\end{array}$} & \multirow[b]{2}{*}{ Region } & \multirow{2}{*}{$\begin{array}{l}\text { U-value criteria } \\
\left(\mathrm{W} / \mathrm{m}^{2} \cdot \mathrm{K}\right)\end{array}$} & \multicolumn{2}{|c|}{ Concrete envelops } & \multicolumn{2}{|c|}{ CLT envelops } & \multirow[b]{2}{*}{ Diff. } \\
\hline & & & $\begin{array}{c}\text { Concrete } \\
\text { thickness }\left(\mathrm{T}_{\mathrm{c}}\right)\end{array}$ & $\begin{array}{c}\text { Insulation } \\
\text { thickness }\left(\mathrm{T}_{\mathrm{i}}\right)\end{array}$ & $\begin{array}{c}\text { CLT } \\
\text { thickness }\left(\mathrm{T}_{\mathrm{clt}}\right) \\
\end{array}$ & $\begin{array}{c}\text { Insulation } \\
\text { thickness }\left(\mathrm{T}_{\mathrm{i}}\right)\end{array}$ & \\
\hline \multirow{4}{*}{$\begin{array}{l}\text { Wall faced } \\
\text { outdoor air }\end{array}$} & Central & 0.21 or less & 180 & 152 & 180 & 109 & 43 \\
\hline & Southern & 0.26 or less & 180 & 121 & 180 & 77 & 44 \\
\hline & Jeju & 0.36 or less & 180 & 84 & 180 & 41 & 43 \\
\hline & Passive & 0.15 or less & 180 & 217 & 180 & 173 & 44 \\
\hline \multirow{4}{*}{$\begin{array}{l}\text { Roof faced } \\
\text { outdoor air }\end{array}$} & Central & 0.15 or less & 180 & 217 & 180 & 174 & 43 \\
\hline & Southern & 0.18 or less & 180 & 180 & 180 & 136 & 44 \\
\hline & Jeju & 0.25 or less & 180 & 127 & 180 & 83 & 44 \\
\hline & Passive & 0.12 or less & 180 & 274 & 180 & 231 & 43 \\
\hline \multirow{4}{*}{ Bottom floor } & Central & 0.26 or less & 180 & 108 & - & - & - \\
\hline & Southern & 0.31 or less & 180 & 87 & - & - & - \\
\hline & Jeju & 0.41 or less & 180 & 60 & - & - & - \\
\hline & Passive & 0.15 or less & 180 & 204 & - & - & - \\
\hline Interlayer floor & $\begin{array}{c}\text { Central } \\
\text { Southern } \\
\text { Jeju }\end{array}$ & 0.81 or less & 150 & 21 & 150 & 0 & 21 \\
\hline
\end{tabular}

termined by its bulk density and moisture content and can be calculated for a CLT using Eq.

(2) (Stora Enso, 2015).

$k=0.000146 * \rho_{k}+0.035449$

where,

$k:$ thermal conductivity $(\mathrm{W} / \mathrm{m} \cdot \mathrm{K})$

$\rho_{k}$ : characteristic bulk density for $12 \%$ moisture content $\left(\mathrm{kg} / \mathrm{m}^{3}\right)$

\subsection{Density of domestic species}

The density of larix kaempferi and pinus koraiensis was measured at $12 \%$ moisture contents. The specimens $(30 \mathrm{~mm} \times 100 \mathrm{~mm} \times 100 \mathrm{~mm})$ were stored at the $12 \%$ equilibrium moisture content $(\mathrm{EMC})$ condition, temperature $\left(30^{\circ} \mathrm{C}\right)$, humidity $(67 \%)$ in chamber. When the weight change rate was less than $1 \%$, it was assumed that the specimens were reached to the $12 \%$ EMC. After the specimens were reached to $12 \%$ EMC, volume was measured. Then, all specimens were placed in oven to measure oven-dried weight. Moisture contents of specimens were calculated using Eq. 3. The density of samples at $12 \%$ moisture content was calculated using Eq. (4)

$$
\begin{gathered}
\text { Moisture } \\
\begin{array}{c}
\text { Weight at 12\% EMC } \\
\text { contents }
\end{array}
\end{gathered} \frac{- \text { Oven-dried weight }}{\text { Oven-dried weight }} \cdot 100 \text { Eq. (3) }
$$

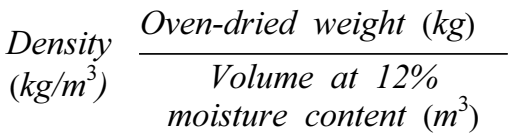




\section{RESULTS and DISCUSSION}

\subsection{Insulation saving effect in Korean apartment using CLT envelops}

The densities of four domestic softwood species, larix kaempferi, pinus koraiensis, pinus densiflora and cryptomeria japonica, at 12\% M.C. were used for deriving the thermal conductivity $(k)$ of CLT using Eq. (2). The densities for larix kaempferi and pinus koraiensis were measured in this study. The densities for untreated species, pinus densiflora and cryptomeria japonica, were obtained from the previously reported values. The calculated $k$ for CLT which made by larix kaempferi, pinus koraiensis, pinus densiflora and cryptomeria japonica were $0.121,0.094,0.104$ and 0.087 $\mathrm{W} / \mathrm{m} \cdot \mathrm{K}$, respectively (Table 3 ). These values are lower than $0.13 \mathrm{~W} / \mathrm{m} \cdot \mathrm{K}$ which is used for commercial CLT in Europe (KLH, 2017). Thus, the $k$ of CLT is conservatively assumed to be $0.13 \mathrm{~W} / \mathrm{m} \cdot \mathrm{K}$, since the $k$ of a CLT is different depending on the density and moisture contents of the wood. If the density and moisture content is lower, the actual thermal conductivity is reduced.

All building envelops in Korea should meet the tabulated criteria in the design standard for energy saving. The U-value of building envelops is generally adjusted by changing the insulation thickness. Thus, the insulation thickness in the existing details (Fig. 2) was adjusted to meet the current criteria in Table 4.

Table 4 shows the minimum insulation thick- ness of concrete and CLT envelops to meet the current criteria. When the concrete was replaced with CLT, the thickness of the insulation decreased about $43 \mathrm{~mm}$ in wall and roof. Especially, no insulation was required at the interlayer floor by CLT. However, a thickness of $21 \mathrm{~mm}$ or more insulation was required for concrete.

\subsection{Modified details for CLT building envelops based on FPInnovation (2011)}

The comparisons of CLT and concrete envelops in Table 4 for the insulation thickness were carried out by simply replacing the concrete to CLT. However, since the CLT is wood based material which is affected by moisture, the composition of envelops needs to be modified to protect the CLT from the moisture. The recommended details for CLT envelopes are presented in the CLT handbook (FPInnovations, 2011). The modified CLT envelops to meet DSEA in South Korea were derived based on FPInnovation (2011) (Fig. 3).

Table 5 shows the insulation thickness of the modified CLT envelops to meet the current DSEA and passive standard. In the modified CLT envelops (Fig. 3), materials, air gap, membrane waterproofing, dry topping, etc. are added. The insulation thickness for wall and roof was decreased by $12 \mathrm{~mm}$ comparing to that of composition from Fig. 2 due to the effect of the thermal conductivity of the added materials. 
Table 5. Thickness (mm) of CLT and insulation for modified CLT envelops

\begin{tabular}{|c|c|c|c|c|c|c|c|}
\hline \multirow[b]{2}{*}{$\begin{array}{l}\text { Building } \\
\text { envelop }\end{array}$} & \multirow[b]{2}{*}{ Region } & \multirow[b]{2}{*}{$\begin{array}{c}\text { U-value criteria } \\
\left(\mathrm{W} / \mathrm{m}^{2} \cdot \mathrm{K}\right)\end{array}$} & \multicolumn{2}{|c|}{ Composition for Fig. 2} & \multicolumn{2}{|c|}{ Composition for Fig. 3} & \multirow[b]{2}{*}{ Diff. $(\mathrm{mm})$} \\
\hline & & & $\begin{array}{l}\text { CLT thickness } \\
\left(\mathrm{T}_{\text {clt }}\right)\end{array}$ & $\begin{array}{c}\text { Insulation } \\
\text { thickness } \\
\left(\mathrm{T}_{\mathrm{i}}\right)\end{array}$ & $\begin{array}{c}\text { CLT thickness } \\
\left(\mathrm{T}_{\mathrm{clt}}\right)\end{array}$ & $\begin{array}{c}\text { Insulation } \\
\text { thickness } \\
\left(\mathrm{T}_{\mathrm{i}}\right)\end{array}$ & \\
\hline \multirow{4}{*}{$\begin{array}{l}\text { Wall faced } \\
\text { outdoor air }\end{array}$} & Central & 0.21 or less & 180 & 109 & 180 & 97 & 12 \\
\hline & Southern & 0.26 or less & 180 & 77 & 180 & 66 & 11 \\
\hline & Jeju & 0.36 or less & 180 & 41 & 180 & 30 & 11 \\
\hline & Passive & 0.15 or less & 180 & 173 & 180 & 162 & 11 \\
\hline \multirow{4}{*}{$\begin{array}{l}\text { Roof faced } \\
\text { outdoor air }\end{array}$} & Central & 0.15 or less & 180 & 174 & 180 & 165 & 9 \\
\hline & Southern & 0.18 or less & 180 & 136 & 180 & 127 & 9 \\
\hline & Jeju & 0.25 or less & 180 & 83 & 180 & 74 & 9 \\
\hline & Passive & 0.12 or less & 180 & 231 & 180 & 221 & 10 \\
\hline \multirow[b]{2}{*}{ Interlayer floor } & Central & & & & & & \\
\hline & $\begin{array}{c}\text { Southern } \\
\text { Jeju }\end{array}$ & 0.81 or less & 150 & 0 & 150 & 0 & 0 \\
\hline
\end{tabular}

In Table 5, the thickness of CLT and concrete was assumed to be same. However, the dimensions of structural member are determined to resist the design loads. Various thickness of CLT can be made with different composition of laminas. The insulation thickness is changed by the CLT thickness mainly due to the thermal conductivity of CLT. Thus, the relationship between the CLT thickness and insulation thickness was derived as shown in Fig. 4. When the CLT thickness is changed from the reference CLT thickness, the required insulation thickness can be calculated using the equation in Fig. 4. The graph in Fig 4 (c) shows that no insulation is required for interlayer floor when the CLT thickness is greater than $100 \mathrm{~mm}$.

In the equations in Fig 4, the slop is affected by the thermal conductivity $(k)$ of a CLT which was determined from the wood density. The $y$-intercept is different depending on the build- ing envelops and the regions, since the y-intercept is affected by the U-value. The slopes were same because the $k$ of CLT was assumed to be $0.13 \mathrm{~W} / \mathrm{m} \cdot \mathrm{K}$. If the $k$ is reduced due to a lower wood density, the required insulation thickness decreases more with the increment of CLT thickness (Fig. 5). According to the derived equation for wall at central region in Fig. 4 (a), as the CLT thickness increases by 10 $\mathrm{mm}$, the insulation thickness decreases about $2.6 \mathrm{~mm}$. If the CLT are made by domestic species, the insulation thickness decreases about $2.8 \mathrm{~mm}$ for larix kaempferi, $3.2 \mathrm{~mm}$ for pinus densiflora, $3.6 \mathrm{~mm}$ for pinus koraiensis, and $3.9 \mathrm{~mm}$ for cryptomeria japonica, as the CLT thickness increases by $10 \mathrm{~mm}$ (Fig. 5). The derived equations in Fig. 4 are conservative for CLT made from the four domestic species because $k$ values for the four species are smaller than $0.13 \mathrm{~W} / \mathrm{m} \cdot \mathrm{K}$. 


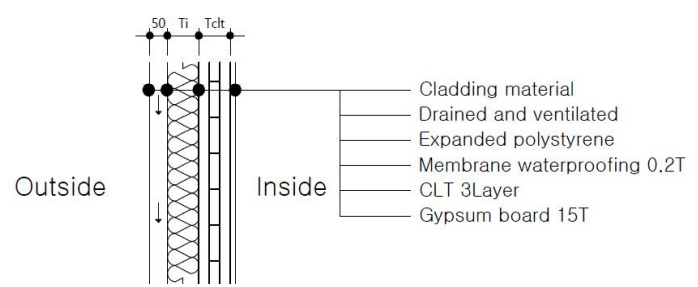

(a) wall

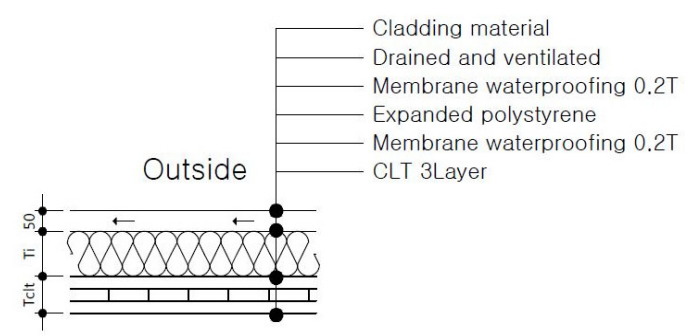

Inside

(b) roof

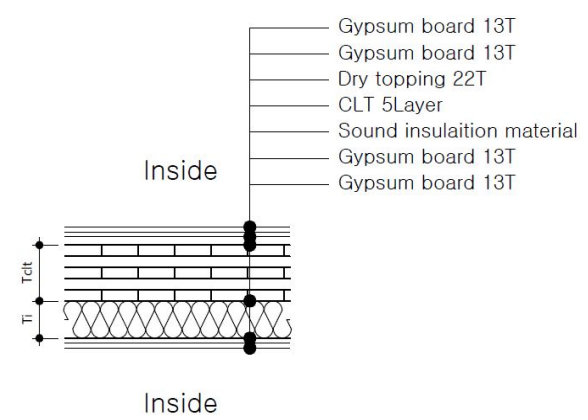

(c) interlayer floor

Fig. 3. Detail of CLT building envelopes (modified from FPInnovations, 2011).

\subsection{Insulation saving effect when 10-story building constructed with CLT instead of concrete}

When a 10 story-virtual building with ten units (Fig. 6) was constructed with either concrete or CLT, the required insulation volume for passive concrete buildings and passive CLT buildings was calculated. The size of a unit was $12,100 \mathrm{~mm}$ by $8,700 \mathrm{~mm}$ by $2,300 \mathrm{~mm}$ (Fig.

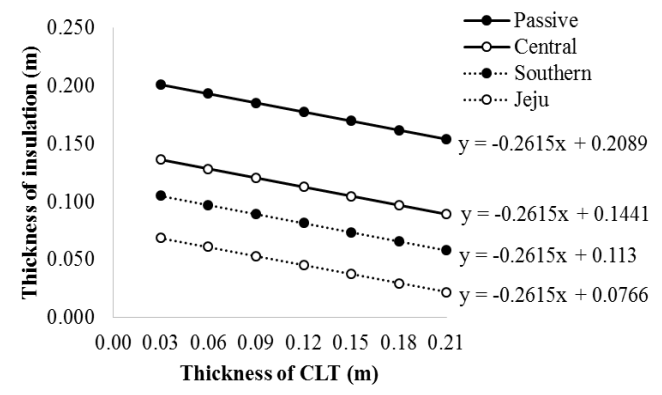

(a) wall

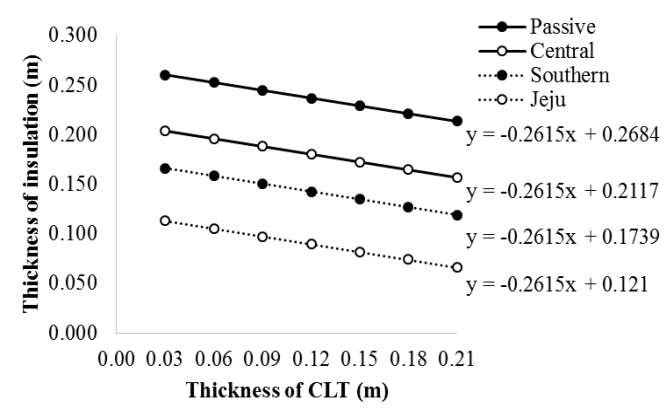

(b) roof

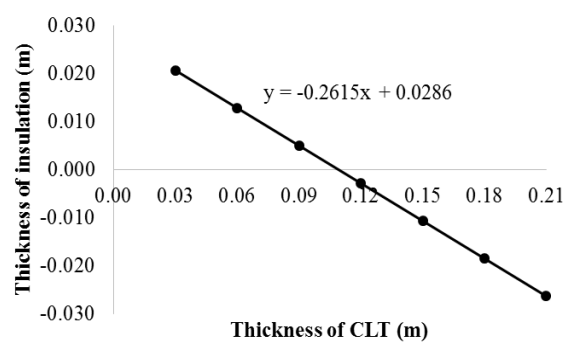

(c) interlayer floor

Fig. 4. Relationship between CLT thickness and insulation thickness to satisfy the U-value criteria for central, southern, Jeju region and passive house (thermal conductivity of CLT was assumed to be $0.13 \mathrm{~W} / \mathrm{m} \cdot \mathrm{K})$.

1). For the CLT building, the compositions of CLT from Fig. 3 were used and the required insulation thicknesses are listed in Table 5.

The required insulation volumes for CLT and concrete at each floor were calculated by multiplying a envelop area (Table 1) by an in- 


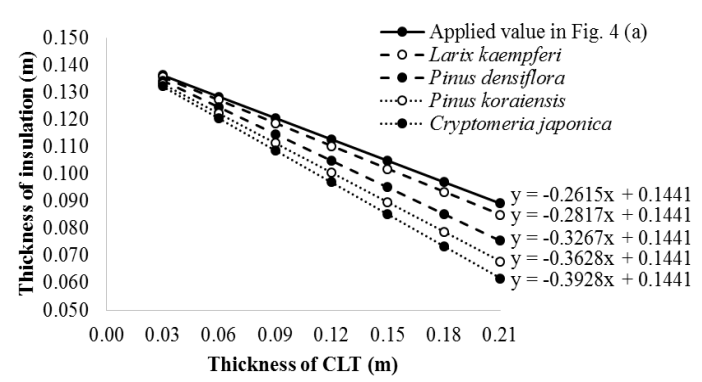

Fig. 5. Relationship of CLT thickness and insulation thickness depending on the thermal conductivity of wood including four domestic softwoods (applied value in Fig. 4: $0.13 \mathrm{~W} / \mathrm{m} \cdot \mathrm{K}$, larix kaempferi: $0.121 \mathrm{~W} / \mathrm{m} \cdot \mathrm{K}$, pinus koraiensis: $0.094 \mathrm{~W} / \mathrm{m} \cdot \mathrm{K}$, pinus densiflora: $0.104 \mathrm{~W} / \mathrm{m} \cdot \mathrm{K}$, cryptomeria japonica: $0.087 \mathrm{~W} / \mathrm{m} \cdot \mathrm{K})$.

sulation thickness in Table 4 (concrete) and Table 5 (CLT), respectively. The window ratios were reflected in the wall areas. The required insulation volumes for the four side walls at each floor were $15.55 \mathrm{~m}^{3}$ and $11.97 \mathrm{~m}^{3}$ for passive concrete building and passive CLT building, respectively. Thus, as the number of floors increases, about $3.58 \mathrm{~m}^{3}$ of insulation per floor was additionally saved. In the first floor, an insulation volume for the bottom floor, $21.26 \mathrm{~m}^{3}$, was added to the insulation volume for the walls. Because CLT was not used for bottom floor, the required insulation volume for bottom floor in CLT building was same that in concrete building. In the 10th floor, an additional insulation volume for the roof was added to the insulation volume for the four side walls. The required insulation volumes for the roof were 28.84 and $23.79 \mathrm{~m}^{3}$ for concrete building and CLT building, respectively.

As a results, about $205.84 \mathrm{~m}^{3}$ of insulation is required to design a 10-story building that

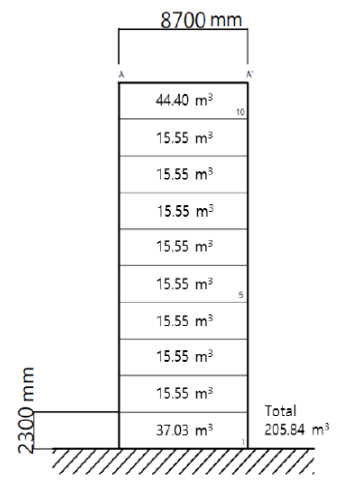

(a) concrete frame

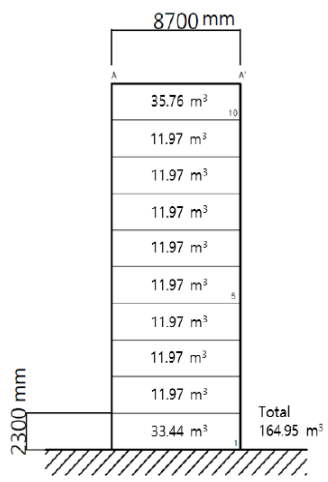

(b) cross laminated timber frame
Fig. 6. Insulation volume required for a 10 story passive apartment house (floor area: $105.27 \mathrm{~m}^{2}$, applied insulation thickness and envelops composition for concrete frame: Table 4 and Fig. 2, applied insulation thickness and envelops composition for CLT frame: Table 5 and Fig. 3).

meets the passive house criteria with concrete frame. In CLT building, the same dimension of building needs about $164.95 \mathrm{~m}^{3}$ of insulation. It shows that about $40.89 \mathrm{~m}^{3}$ of insulation was saved in CLT building compared to concrete building.

\section{CONCLUSIONS}

In this study, the required insulation thicknesses for CLT building envelops were analyzed to satisfy the design standard for energy saving and passive standard in South Korea. When the thickness of $180 \mathrm{~mm}$ CLT was used for wall as a structural purpose, the required insulation thicknesses were 97, 66, 30 and 162 $\mathrm{mm}$ in central, southern, Jeju island and passive house, respectively. These values are reduced $36,45,64$ and $25 \%$ than the required insulation thickness for concrete envelops, respectively. 
The insulation thicknesses for $180 \mathrm{~mm}$ CLT envelops in roof were also $24,29,42$ and $19 \%$ reduced than those for the same size of concrete envelops, respectively. Especially, no insulation was required at the interlayer floor when the CLT thickness was greater than 100 $\mathrm{mm}$. Therefore, the insulation saving effect can be expected using CLT instead of concrete in Korean apartment houses due to the lower thermal conductivity of wood.

\section{ACKNOWLEDGEMENTS}

This study was carried out with the support of 'Forest Science \& Technology Projects (Project No. 2017051B101719BB02)' provided by Korea Forest Service.

\section{REFERENCES}

Brandner, R., Flatscher, G., Ringhofer, A., Schickhofer, G., Thiel, A. 2016. Cross laminated timber (CLT): overview and development. European Journal of Wood and Wood Products 74(3): $331 \sim 351$.

CTBUH. 2017. Tall Buildings in Numbers, Tall Timber: A Global Audit. Council on Tall Buildings and Urban Habitat.

Fadai, A., Winter, W., Gruber, M. 2012. Wood based construction for multi-storey buildings. The potential of cement bonded wood composites as structural sandwich panels. In World Conference on Timber Engineering, Auckland, New Zealand: 125 133.

FPInnovations. 2011. CLT Handbook: Crosslaminated timber. Canadian Edition. Special Publication SP-528E. Edited by S. Gagnon and C. Privu. FPInnovations, Quebec, QC, Canada.
Jeong, S.H., Park, B.S. 2008. Wood properties of the useful tree species grown in Korea. Korea Forest Research Institute 29: 211.

Ji, C., Cao, W., Chen, Y., Yang, H. 2016. Carbon balance and contribution of harvested wood products in China based on the production approach of the intergovernmental panel on climate change. International Journal of Environmental Research and Public Health 13(11): 1132.

Kim, S., Pak, J.S. 2015. Insulation details and energy performance of post-beam timber house for insulation standards. Journal of the Korean Wood Science and Technology 43(6): 876 883.

Kim S., Park, J.S., Lee, J.J. 2013a. Improvement of energy efficiency in wood frame house with energy efficient methods. Journal of the Korean Wood Science and Technology 41(1): 77 86.

Kim S., Yu, S., Seo, J., Kim, S. 2013b. Thermal performance of wooden building envelope by thermal conductivity of structural members. Journal of the Korean Wood Science and Technology 41(6): 515 527.

KLH. 2017. The technical characteristics of KLH cross-laminated timber panels. KLH UK Ltd.

Lee, S.S. 2017. Load carrying capacity of utgulisanji connection under different moisture contents. M.S. Thesis, Chonnam National University. South Korea.

Mallo, M.F.L., Espinoza, O. 2014. Outlook for cross-laminated timber in the United States. BioResources 9(4): 7427 7443.

Ministry of Land, Infrastructure and Transport. 2017. the design standard for energy saving.

PHIK. 2017. Definition and requirements of passive house. Passive House Institute Korea.

Rafiei, M.H., Adeli, H. 2016. Sustainability in highrise building design and construction. The Structural Design of Tall and Special Buildings 25(13): $643 \sim 658$. 
Seo, J., Kang, Y., Kim, S. 2016. Wood thermal conductivity database construction for the application of building energy simulation. Journal of the Korea Furniture Society 27(2): 122 127.

Stora Enso. 2015. Thermal performance of CLT solid-wood elements. Stora Enso Wood Products (http://www.clt.info).

Yoo H., Hyun, S.K., Hong, H. 2002. Effects of various factors on the energy consumption of Korean-Style apartment houses. Korean Journal of Air-Conditioning and Refrigeration Engineering 14(11): 972 980. 